\title{
Physical Maps of 4p16.3, the Area Expected to Contain the Huntington Disease Mutation
}

\author{
M: Bućan, ${ }^{*, 1}$ M. Zimmer, ${ }^{* 2}$ W. L. Whaley, † A. PoustKa, † S. Youngman, § B. A. Allitto, $†$

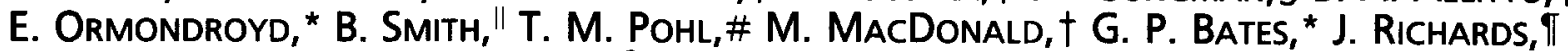 \\ S. Volinia, * T. C. Gilliam, ${ }^{3}{ }^{3}$ Z. Sedlacek, F. S. Collins, T J. J. WAsmuth," \\ D. J. Shaw, $§$ J. F. Gusella, † A-M. Frischauf, * and H. Lehrach ${ }^{\star, 4}$
}

\begin{abstract}
*Imperial Cancer Research Fund, P.O. Box 123, Lincolns Inn Fields, London WC2A3PX, and §Institute of Medical Genetics, University of Wales College of Medicine, Heath Park, Cardiff CF4 4XN, England; †Neurogenetics Laboratory, Massachusetts General Hospital and Department of Genetics, Harvard Medical School, Boston, Massachusetts 20114; $¥ Z M B H$, Im Neuenheimer Feld 282, and \#EMBL, Postfach 1022.40, D-6900 Heidelberg, West Germany; and "Department of Biological Chemistry, California College of Medicine, University of California, Irvine, California 92717; and THoward Hughes Medical Institute, Departments of Internal Medicine and Human Genetics, University of Michigan, Ann Arbor, Michigan 48109
\end{abstract}

Received May 24, 1989; revised August 7, 1989

The gene for Huntington disease, a neurodegenerative disorder with autosomal dominant inheritance, has been localized to the terminal portion of the short arm of human chromosome $4(4 \mathrm{p16.3})$ by linkage analysis. Since eventual isolation of the gene requires the application of high-resolution genetic analysis coupled with long-range DNA mapping and cloning techniques, we have constructed a physical map of the chromosomal region $4 p 16.3$ using more than 20 independently derived probes. We have grouped these markers into three clusters which have been ordered and oriented by genetic and somatic cell genetic mapping information. The mapped region extends from D4S 10 (G8) toward the telomere and covers minimally $5 \mathrm{Mb}$. 1990 Academic Press, Inc.

\section{INTRODUCTION}

Huntington's disease (HD) is an inherited, autosomal dominant disorder affecting the central nervous system. The disease is characterized by progressive abnormal movements, psychological changes, and dementia which result in complete disability and death, usually 15-20 years after the appearance of the first symptoms. Neuropathological changes are caused by premature nerve cell death which is most prominent in the striatum. The disease becomes apparent usually

\footnotetext{
${ }^{1}$ Present address: The Wistar Institute, 36th Street at Spruce, Philadelphia, PA 19104.

${ }^{2}$ Present address: The Salk Institute, PO Box 85800, San Diego, CA 92138-9216.

${ }^{3}$ Present address: College of Physicians and Surgeons, Columbia University, 722 West 168th St, Box 23, New York, NY 10032.

${ }^{4}$ To whom reprint requests should be addressed.
}

in the fourth or fifth decade of life; however, the age of onset and severity of symptoms are variable and depend in some cases on the parental origin of the gene (Hayden, 1981). Unexpectedly, individuals with a high probability of being homozygous for the $H D$ mutation do not differ in clinical expression from typical $H D$ heterozygotes (Wexler et al., 1987).

The biochemical defect causing cell death is not un derstood. However, considerable progress has been made toward localization and possible isolation of the mutant gene. The $H D$ gene was originally mapped by genetic linkage to the $D 4 S 10$ locus defined by the polymorphic DNA probe G8, which was assigned by somatic cell hybrids (Gusella et al., 1983; MacDonald et al., 1987; Smith et al., 1988), deletion analysis (Gusella et al., 1985), and in situ hybridization (Magenis et al., 1986; Landegent et al., 1986) close to the telomere of the short arm of chromosome 4. Genetic analysis, including multipoint linkage data, demonstrated that $H D$ maps $4 \mathrm{cM}$ distal to $D 4 S 10$ (Gilliam et al., 1987b). Additional DNA loci, D4S43 (C4H) and D4S95 (BS674), were identified and initially did not show recombination with HD (Gilliam et al., 1987a; Wasmuth et al., 1988). However, genetic analysis using several, more informative DNA probes from the D4S43 locus have identified recombination events between $H D$ and D4S43 placing this locus proximal to the disease gene (MacDonald et al., 1989).

To identify closer and, if possible, flanking markers, a number of new probes defining loci mapping distal to the $D 4 S 10$ locus were isolated from sorted chromosome libraries and libraries which had been constructed from HHW693, a cell line containing a part of human chromosome 4 (4p15-4pter) translocated onto a fragment of $5 p$ on a hamster background (Was- 
muth et al., 1986). This somatic cell hybrid was used to generate a total lambda library (Smith et al., 1988), a cosmid library (Bućan, unpublished), and a NotI linking library (Pohl et al., 1988), from which human clones were identified by hybridization to species-specific repeat sequences. The loci defined by these probes were mapped relative to each other and, where applicable, relative to the position of the $H D$ mutation by somatic cell genetics (Smith et al., 1988; MacDonald et al., 1987) and linkage analysis (Gusella et al., 1983; Gilliam et al., 1987a; Wasmuth et al., 1988).

The localization of new sequences by genetic linkage analysis can indicate their linear order and their position with respect to the $H D$ gene. Genetic linkage analysis, however, requires highly polymorphic markers and is often incapable of resolving neighboring loci. Pulsed-field gel electrophoresis (PFGE) (Schwartz and Cantor, 1984; Carle et al., 1986; Chu et al., 1986; Barlow and Lehrach, 1987) is a physical mapping technique that provides the resolution required to identify regions short enough to be analyzed by molecular techniques and to assign exact physical distances to the genetically determined intervals. In addition, the establishment of a physical map contributes to the information derived from genetic analysis, since data from physically ordered loci can be easily combined with genetic linkage data. Comparison of the genetic and physical map is necessary for the identification of those DNA fragments which are likely to be closest to the $H D$ gene. The construction of the physical map of the chromosomal region around the $H D$ gene is also of particular interest since it has been suggested that recombination is increased near the telomeres (Laurie and Hulten, 1985a,b).

We have placed all available DNA probes from the 4p16.3 region in a physical map that spans at least 5 $\mathrm{Mb}$. Data from linkage analysis in reference and $\mathrm{HD}$ families (MacDonald et al., 1989; Youngman et al., 1989) allow the three map segments to be ordered and oriented relative to each other and to the $H D$ gene. Several lines of evidence indicate that most of the DNA present in the telomeric region of chromosome 4 is represented on the map.

\section{MATERIALS AND METHODS}

\section{Cells and DNA}

DNA for PFGE analysis was prepared from lymphoblastoid cell lines and peripheral blood leukocytes. Lymphoblastoid cell lines used were GM1416B (karyotype 48,XXXX; NIGMS Human Genetic Cell Repository, Camden, NJ); the cell lines GusHM1, GusHM2, and GusHM3 isolated from patients with a high probability of being homozygous for $\mathrm{HD}$; and the non-Huntington patient-derived cell lines AH148 and AH150 (kindly provided by M. Siniscalco), EJ167T12 (kindly provided by P. Goodfellow and I. Pickford), Gus115, and Gus641.

High-molecular-weight DNA from lymphoblastoid cell lines was prepared in agarose blocks according to published protocols (Herrmann et al., 1987). High-molecular-weight DNA from blood was prepared by selective lysis of the erythrocytes (Herrmann and Frischauf, 1987). The leukocyte pellet was washed three times in lysis buffer and once with phosphate-buffered saline (PBS), and the cells were resuspended in the same buffer at a concentration of $7 \times 10^{5}$ cells per 40 $\mu \mathrm{l}$ PBS and used similarly in the preparation of agarose blocks.

\section{DNA Probes}

The probes used in PFGE analysis are listed and described in Table 1 . Insert DNA was purified by electrophoresis on low-melting-point (LMP) agarose gels, followed by digestion of the agarose with agarase $(\mathrm{Bu}-$ can et al., 1986; Michiels et al., 1987). Hybridization probes were radiolabeled to a specific activity of $3 \times 10^{9}$ $\mathrm{cpm} / \mu \mathrm{g}$ with [ $\left.{ }^{32} \mathrm{P}\right] \mathrm{dATP}$ using the Klenow fragment of DNA polymerase I and random hexamer priming (Feinberg and Vogelstein, 1983). To obtain longer hybridization probes we have used a reduced concentration of random hexamers (1/16th of the amount recommended by Feinberg and Vogelstein).

\section{Pulsed-Field Gel Electrophoresis}

The methods of pulsed-field gel electrophoresis, including DNA preparation in agarose blocks, preparation of yeast chromosomes and phage multimers used as size markers, restriction analysis and alkaline blotting onto GeneScreen filters, and the hybridization conditions have been described before (Herrmann et al., 1986, 1987; Church and Gilbert, 1984). Contour clamped homogeneous electric field (CHEF) electrophoresis was carried out in an electrophoresis apparatus similar to the one described by Chu et al. (1986) constructed at the EMBL, Heidelberg, West Germany. Agarose gels $(0.75 \%)$ were electrophoresed in $0.25 \times$ TBE buffer for $40 \mathrm{~h}$ at $14^{\circ} \mathrm{C}$ at a voltage gradient of 5 $\mathrm{V} / \mathrm{cm}$, using a switching time of $45 \mathrm{~s}$ for the separation of DNA fragments up to $600 \mathrm{~kb}$ in length or of $100 \mathrm{~s}$ for the separation of fragments up to $1500 \mathrm{~kb}$. Size markers used were chromosomes of Saccharomyces cerevisiae, strain YP148, kindly provided by P. Hieter and multimers of the phage EMBL3A (monomer length $42.5 \mathrm{~kb})$.

\section{Derivation of Clones by Chromosome Jumping}

Clones 252 and J252 were derived from the human NotI jumping library which was constructed from cell line GM1416B using BamHI to recut and insert the 
DNA into the vector (Poustka et al., 1987; Poustka and Lehrach, 1988).

\section{RESULTS AND DISCUSSION}

\section{Probes and Loci}

The names of probes and loci, their sources, and a short description of their derivation are given in $\mathrm{Ta}$ ble 1 .

The sequences corresponding to the probes listed in Table 1 are deleted in cell lines H64 and HHW847, localizing them to the most distal subregion of $4 \mathrm{p} 16.3$ (Smith et al., 1988; MacDonald et al., 1987). Their presence or absence in the cell line HHW842, human/ Chinese hamster hybrid, derived from a patient with a large interstitial deletion that appears to involve 4p16.3-4p14, but contains the terminal part of $4 \mathrm{p}$ (Smith et al., 1988; MacDonald et al., 1987), allowed further classification into two subregions: the proximal subregion, B, contains 7 loci including $D 4 S 10$ (G8), D4S43 (C4H), and D4S95 (BS674), while the distal subregion, A, contains 12 additional loci (Table 1).

Loci from the two cytogenetically defined subregions were further analyzed by linkage studies, carried out in both reference and HD families. This allowed the establishment of a most "likely order" of the more informative marker loci (Gusella et al., 1983; Gilliam et

TABLE 1

List of Molecular Probes Used in PFGE Analysis

\begin{tabular}{|c|c|c|c|c|c|}
\hline Probe & Locus & Source & Region & Description & Ref. \\
\hline G8 (pK082) & $D 4 S 10$ & Random marker & B & $E c o$ RI, 5 kb & (14) \\
\hline $\begin{array}{l}\text { HDA29 } \\
\text { (HDA RB1.6) }\end{array}$ & $D 4 S 81$ & Jump from G8 & B & $E c o$ RI-BamHI $1.6 \mathrm{~kb}$ & (36) \\
\hline B.I14 & $D 4 S 126$ & HHW693 cosmid library & B & HindIII, $1.6 \mathrm{~kb}$ & Allitto, unpublished \\
\hline YNZ32 & $D 4 S 125$ & VNTR marker & B & $R s a \mathrm{I}, 3.3 \mathrm{~kb}$ & $(30)$ \\
\hline RJ56 & $D 4 S 127$ & HHW693 cosmid library & B & HindIII, $0.3 \mathrm{~kb}$ & Allitto, unpublished \\
\hline BS674 & $D 4 S 95$ & HHW693 lambda library & B & $E c o \mathrm{RI}, 1 \mathrm{~kb}$ & (38) \\
\hline $\mathrm{C} 4 \mathrm{H}$ & $D 4 S 43$ & $\begin{array}{l}\text { Chromosome } 4 \text { sorted } \\
\text { library }\end{array}$ & B & HindIII, $3.0 \mathrm{~kb}$ & (12) \\
\hline $39 \mathrm{~S} 4.8$ & $D 4 S 43$ & Cosmid walk from $\mathrm{C} 4 \mathrm{H}$ & B & Sst I, 4.8 & This paper \\
\hline $42 \mathrm{RB} 1.8$ & $D 4 S 43$ & Cosmid walk from $\mathrm{C} 4 \mathrm{H}$ & B & EcoRI-BamHI, $1.8 \mathrm{~kb}$ & This paper \\
\hline BS678 & $D 4 S 96$ & HHW693 lambda library & A & $E c o R I, 0.8 \mathrm{~kb}$ & (38) \\
\hline BS731 & $D 4 S 98$ & HHW693 lambda library & $A$ & BamHI, $1.3 \mathrm{~kb}$ & (38) \\
\hline BS385 & $D 4 S 99$ & HHW693 lambda library & A & HindIII, 4 kb & Smith, unpublished \\
\hline BS854 & $D 4 S 97$ & HHW693 lambda library & A & Pst I, $0.6 \mathrm{~kb}$ & (38) \\
\hline D5 & $D 4 S 90$ & $\begin{array}{l}\text { Chromosome } 4 \text { sorted } \\
\text { library }\end{array}$ & A & $E c o$ RI, $1.5 \mathrm{~kb}$ & (43) \\
\hline 157.1BN1.5 & D4S111 & HHW693 linking library & A & BamHI-NotI $1.5 \mathrm{~kb}$ & (31) \\
\hline 157.6R8.9 & $D 4 S 111$ & Cosmid walk from 157 & A & $E c o R I, 8.9$ kb & This paper \\
\hline 252BN4.0 & $D 4 S 115$ & Jump from 157 & A & BamHI-NotI, $4.0 \mathrm{~kb}$ & This paper \\
\hline $\mathrm{J} 252 \mathrm{~K} 0.5$ & D4S112 & Jump from 157 & A & $K p n I, 0.6 \mathrm{~kb}$ & This paper \\
\hline W92 & D4S114 & $\begin{array}{l}\text { Cloning of DNA } \\
\text { fragments from PFG }\end{array}$ & A & KpnI-HindIII, 0.6 kb & (42) \\
\hline $102 \mathrm{BN} 4.0$ & D4S113 & HHW693 linking library & A & BamHI-NotI, $4.0 \mathrm{~kb}$ & $(31)$ \\
\hline $62.5 \mathrm{BN} 2.8$ & D4S113 & HHW693 linking library & A & BamHI-NotI, $2.8 \mathrm{~kb}$ & (31) \\
\hline 62.10RB3.5 & $D 4 S 113$ & Cosmid walk from 62 & A & EcoRI, $3.5 \mathrm{~kb}$ & This paper \\
\hline 13353.5 & D4S113 & HHW693 linking library & A & Salı, $3.5 \mathrm{~kb}$ & (31) \\
\hline $133 \mathrm{~S} 2.8$ & $D 4 S 113$ & HHW693 linking library & A & SalI, $2.8 \mathrm{~kb}$ & (31) \\
\hline $417 \mathrm{R} 2.8$ & & Cosmid walk from 417 & A & $E c o \mathrm{RI}, 2.8 \mathrm{~kb}$ & This paper \\
\hline 417BN1.5 & & HHW693 linking library & A & BamHI-NotI, $1.5 \mathrm{~kb}$ & (31) \\
\hline $107 \mathrm{S1.8}$ & & HHW693 linking library & A & Sall, $1.8 \mathrm{~kb}$ & This paper \\
\hline 107BN0.5 & & HHW693 linking library & A & BamI-NotI, $0.5 \mathrm{~kb}$ & This paper \\
\hline J107S3A0.9 & & Jump from P107 & A & $S a u 3 \mathrm{~A}, 0.9 \mathrm{~kb}$ & 'This paper \\
\hline cJ107.1BN2.5 & & Cosmid walk from J107 & A & BamHI-NotI, $2.5 \mathrm{~kb}$ & This paper \\
\hline
\end{tabular}


al., 1987a; Wasmuth et al., 1988; Whaley et al., 1989; MacDonald et al., 1989; Youngman et al., 1989; Allitto et al., in preparation). Loci from subregion $\mathrm{B}$ have been assigned to three groups: the most proximal locus $D 4 S 10$ (G8); a second locus, D4S81 (HDA29), placed distal to $D 4 S 10$ (G8) by two recombination events (Richards et al., 1988); and the most distal group, consisting of loci D4S125 (YNZ32), D4S95 (BS674), and $D 4 S 43(\mathrm{C} 4 \mathrm{H})$. Loci mapping to the terminal subregion A all lie distal to $D 4 S 43(\mathrm{C} 4 \mathrm{H})$, and can also be assigned to three distinct groups: the group defined by loci D4S113 (P62, P102), D4S114 (W92), and D4S98 (BS731) maps nearest to D4S43 (C4H); a second group, defined by loci D4S115 (P252), D4S111 (P157), and D4S96 (BS678), was placed distal to the first group by recombination events; while the marker D5 (D4S90) defines the most distal locus analyzed.

Combination of cytogenetic and linkage data therefore allowed the ordering of loci from 4p16.3: [D4S10 (G8)]-[D4S81 (HDA29)]-[D4S125 (YNZ32), D4S95 (BS674), D4S43 (C4H)]-[D4S113 (P62, P102), D4S114 (W92), D4S98 (BS731)]-[D4S115 (P252), D4S111 (P157), D4S96 (BS678)]-[D4S90 (D5)].

\section{Strategy of Physical Mapping}

To construct a physical map of the chromosomal region around the $H D$ gene 21 probes from $4 \mathrm{p} 16.3$ were analyzed by PFGE analysis using restriction enzymes which cut infrequently in mammalian DNA. Preliminary experiments had shown that 4p16.3 contains many $\mathrm{CpG}$ islands and therefore probes from that region detect relatively small bands in DNA digested with rare cutting enzymes containing only $\mathrm{C}$ and $\mathrm{G}$ in their recognition sites (BssHII, EagI, and NotI). In addition to the enzyme NotI, we used the enzymes MluI and NruI which contain A and $\mathrm{T}$ as well as two $\mathrm{CpG}$ sequences in their recognition sites. A major fraction, 73\% (Brown and Bird, 1986), of MluI and NruI sites is expected to occur outside $\mathrm{CpG}$ islands. MluI and NruI, despite their shorter recognition sequence, often generate larger DNA fragments than NotI in regions rich in CpG islands (Brown, 1988).

Two different sources of DNA were used for the preparation of filters: peripheral blood leukocytes and the lymphoblastoid cell line GM1416B containing four X chromosomes (48,XXXX karyotype). Preliminary analysis suggested that most regions within $4 \mathrm{p} 16.3$ are undermethylated in the DNA from the cell line GM1416B in comparison to DNA isolated from peripheral blood leukocytes. It often proved possible to demonstrate physical linkage over longer distances in digests of blood leukocyte DNA, while the hybridization pattern in digests of GM1416B DNA allowed more precise localization and distance determination. In addition, changes in band positions due to differential site methylation were used to confirm or exclude the detection of the same bands by two different probes. This resulted in two different maps that can be aligned at points corresponding to sites that are cleaved in both DNAs.

Probes were successively hybridized to blood and cell line DNA, digested with MluI, NruI, NotI, and combinations of these three enzymes (Fig. 1). On the basis of fragment sizes detected by each probe (results summarized in Table 2) a map consisting of three continuous segments was constructed (shown as segments I, II, and III in Fig. 2).

\section{Segment I}

Map segment I (Fig. 2A) was constructed using three independently isolated clones, G8 (D4S10) (Gusella et $a l ., 1983)$, YNZ32 (D4S125) (Nakamura et al., 1988), and BJ14 (D4S126) (Allitto et al., in preparation), and the probe HDA29 (D4S81) obtained by chromosome jumping from G8 (Richards et al., 1988). D4S81 is located $200 \mathrm{~kb}$ distal to $D 4 S 10$ and a partial restriction map covering the region surrounding these two probes was reported by Richards et al., (1988). D4S10, D4S125, $D 4 S 126$, and $D 4 S 81$ were mapped to the cytogenetic subregion $B$ by a somatic cell hybrid panel (MacDonald et al., 1987, 1989; Allitto et al., in preparation).

The analysis of the hybridization pattern in blood DNA showed that the probes HDA29, BJ14, G8 (subclone pK082), and YNZ32 are in close physical proximity; HDA29, BJ14, and YNZ32 are located on the same $420-\mathrm{kb}$ NotI fragment and G8 is located on an adjacent Notl fragment of the same size (Fig. 2A; Table 2). Hybridization to the less methylated DNA from the cell line GM1416B established the order G8-(HDA29, BJ14)-YNZ32 and allowed more precise localization of the probe sequences (Fig. 2A). The resulting map segment (segment I) covers $1500 \mathrm{~kb}$ and is oriented genetically from the observation of recombinant chromosomes. $D 4 S 10(\mathrm{G} 8)$ was positioned proximal to the other markers D4S81 (HDA29), D4S126 (BJ14), and D4S125 (YNZ32). Two recombination events separate D4S10 and D4S81 (Richards et al., 1988), reflecting the high recombination frequency in the region between D4S10 and D4S81 (Richards et al., 1988; Allitto et al., in preparation).

\section{Segment II}

The map of the next segment (segment II, Fig. 2B) contains two groups of probes, mapping respectively to the proximal and distal subregions of $4 \mathrm{p} 16.3$, and therefore straddles the cytogenetically defined boundary between these two subregions. The physical map of part of segment II which is not contained in HHW842, and therefore proximal to the boundary between regions $B$ and regions $A$, is based on the analysis of three probes from the locus $D 4 S 43(\mathrm{C} 4 \mathrm{H}, 39 \mathrm{~S} 4.8$, and $42 \mathrm{RB} 1.8$ ) and the independently isolated clones 
A

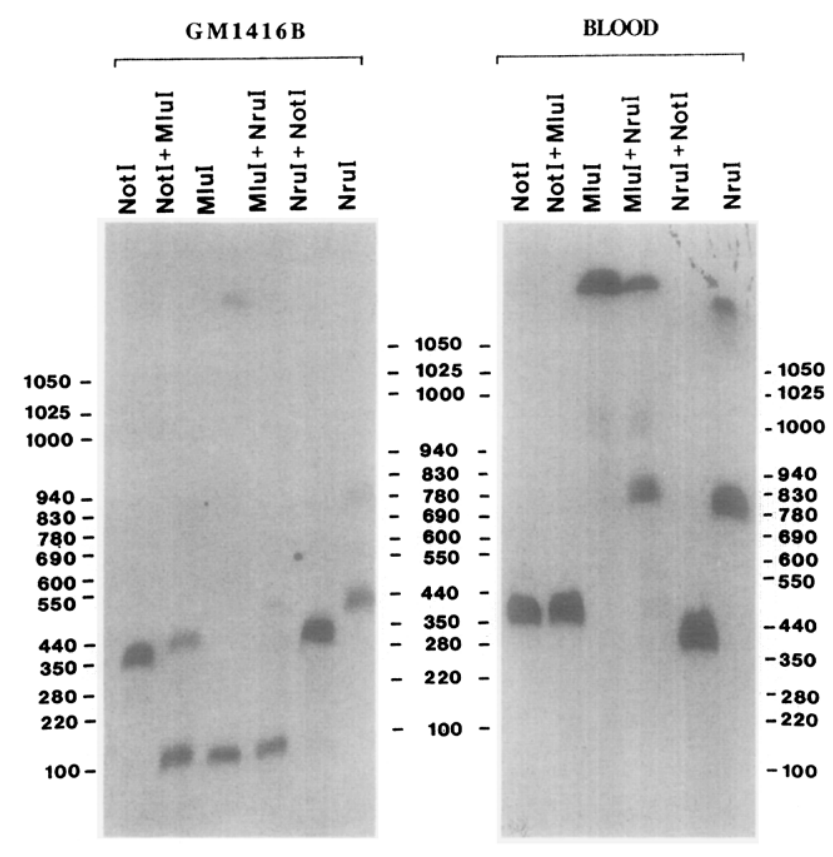

G8(pKO82)
B
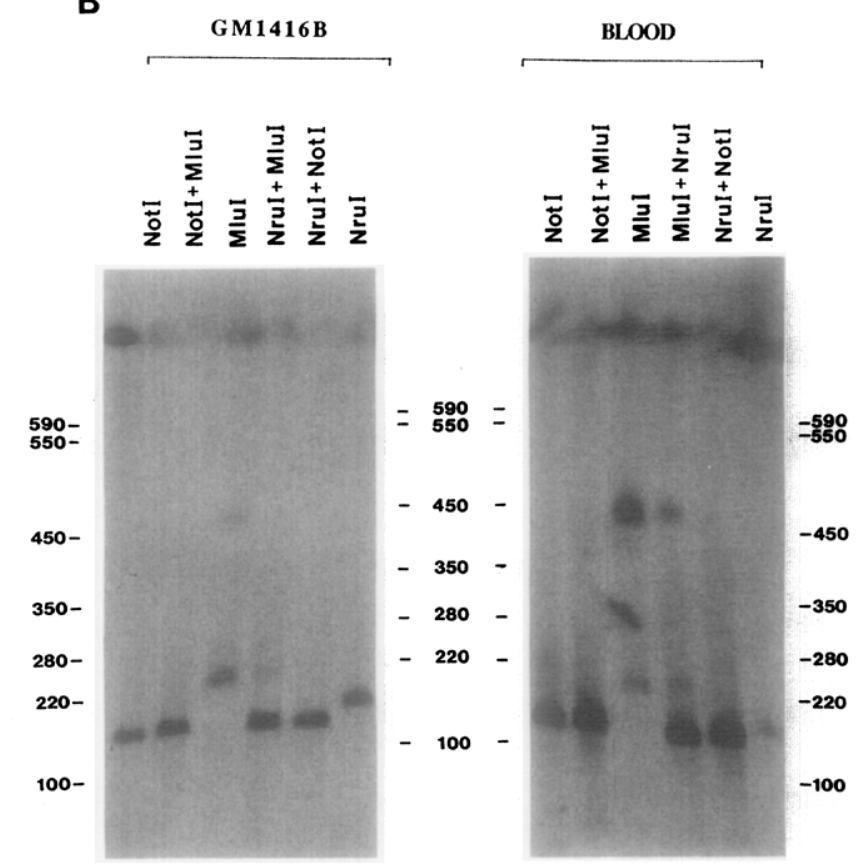

W92

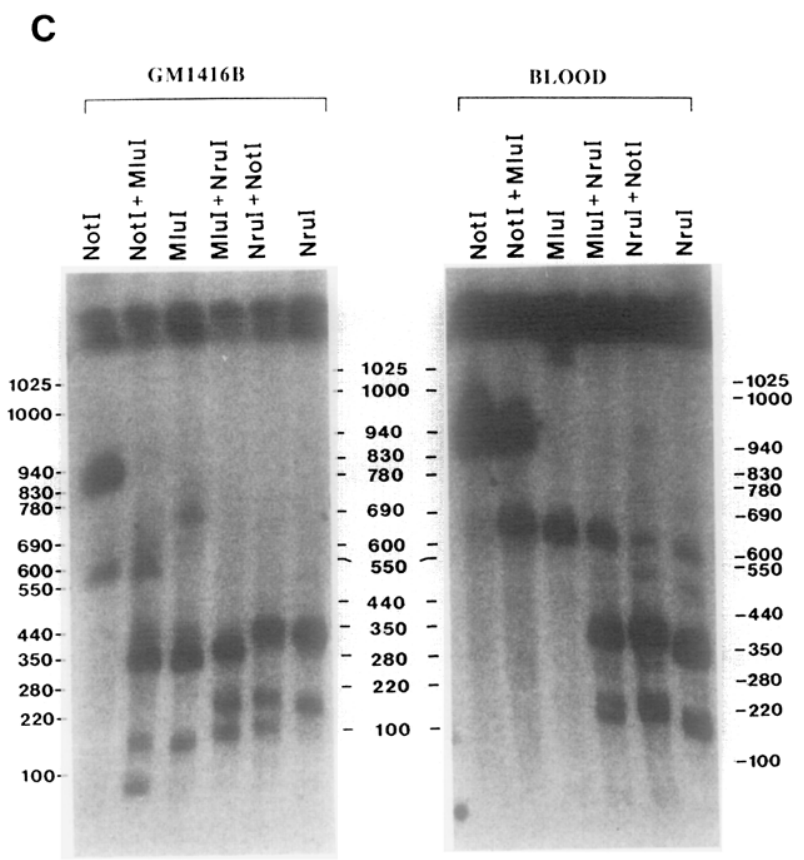

D 5

FIG. 1. Pulsed-field gel analysis of DNA isolated from blood and GM1416B cell line. High-molecular-weight DNA was prepared from peripheral blood leukocytes and the cell line GM1416B. DNA samples were digested with NotI, MluI, NruI, and combinations of these enzymes. Electrophoresis was carried out for $40 \mathrm{~h}$ in a $0.75 \%$ agarose gel at an electric field gradient of $5 \mathrm{~V} / \mathrm{cm}$, at $14^{\circ} \mathrm{C}$. Separation of DNA fragments up to $600 \mathrm{~kb}(\mathrm{~B})$ was obtained by electrophoresis with a pulse time of $45 \mathrm{~s}$; separation up to $1500 \mathrm{~kb}(\mathrm{~A}, \mathrm{C})$ was obtained with a pulse time of 100 s. Filters were analyzed by hybridization with the probes pK082 (A), W92 (B), and D5 (C). Thirty probes listed in Table 1 were successively hybridized to the filters shown in Fig. 1. Observed fragment sizes are listed in Table 2. 
BUC̄AN ET AL.

TABLE 2

Summary of Fragment Sizes

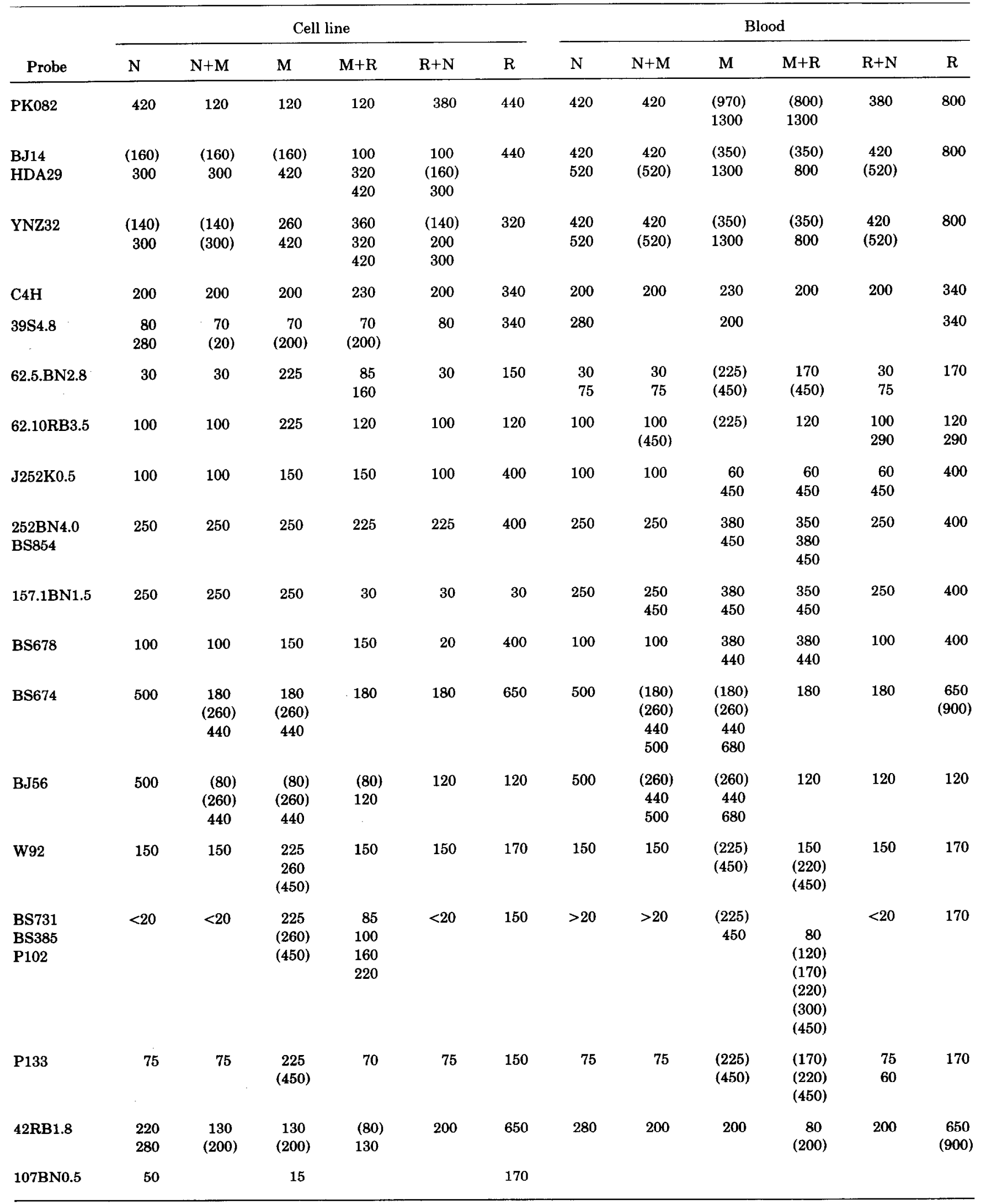


TABLE 2-Continued

\begin{tabular}{|c|c|c|c|c|c|c|c|c|c|c|c|c|}
\hline \multirow[b]{2}{*}{ Probe } & \multicolumn{6}{|c|}{ Cell line } & \multicolumn{6}{|c|}{ Blood } \\
\hline & $\mathbf{N}$ & $\mathbf{N}+\mathbf{M}$ & $\mathbf{M}$ & $\mathbf{M}+\mathbf{R}$ & $\mathrm{R}+\mathrm{N}$ & $\mathrm{R}$ & $\mathbf{N}$ & $\mathbf{N}+\mathbf{M}$ & $\mathbf{M}$ & $\mathbf{M}+\mathbf{R}$ & $R+N$ & $\mathbf{R}$ \\
\hline J107 & 50 & 50 & 230 & 230 & 50 & 340 & & & & & & \\
\hline C107.1 & 200 & 200 & 230 & 200 & 200 & 340 & & & & & & \\
\hline $417 \mathrm{BN} 1.8$ & & & & & & & & & & & & \\
\hline D5 & $\begin{array}{c}(600) \\
850\end{array}$ & $\begin{array}{c}(50) \\
(100) \\
300 \\
600\end{array}$ & $\begin{array}{c}(100) \\
300\end{array}$ & $\begin{array}{c}(100) \\
(180) \\
300\end{array}$ & $\begin{array}{c}(100) \\
(180) \\
350\end{array}$ & $\begin{array}{c}(180) \\
300\end{array}$ & 850 & $\begin{array}{l}650 \\
850\end{array}$ & $\begin{array}{r}650 \\
1000\end{array}$ & $\begin{array}{c}(180) \\
350 \\
(600)\end{array}$ & $\begin{array}{c}(180) \\
350 \\
(600)\end{array}$ & $\begin{array}{c}(180) \\
350 \\
(600)\end{array}$ \\
\hline
\end{tabular}

Note. Partially cut bands are indicated in parentheses. All restriction fragment sizes are approximate values ( $\pm 10 \%)$. To confirm the identity of shared bands, several gels run with different pulse times were analyzed. Sizes of partially cut bands larger than $1000 \mathrm{~kb}$ are determined as sums of shorter bands due to the larger uncertainty associated with direct size determination of high-molecular-weight bands.

BS674 (D4S95) and BJ56 (D4S127). D4S43 maps 4 cM distall to D4S10 (Gilliam et al., 1987a) but two crossovers place it proximal to the $H D$ gene (MacDonald et al., 1989). The locus $D 4 S 43$ was extended by chromosome walking from $\mathrm{C} 4 \mathrm{H}$ and overlapping cosmids covering $180 \mathrm{~kb}$ were isolated (Gilliam et al., 1987a; Zimmer et al., unpublished). A large number of probes isolated from these cosmids were used in genetic linkage analysis and in PFGE mapping studies.

D4S95 defined by probe BS674 was found to be located distal to $D 4 S 10$ (G8) by linkage analysis. Initial results did not show recombination with the $H D$ locus (Wasmuth et al., 1988), placing it within $0-1.5 \mathrm{cM}$ of the gene. Probe BJ56 was isolated as a human clone from a cosmid library derived from cell line HHW693 and localized to region $\mathrm{B}$ by somatic cell genetics.

The map around locus $D 4 S 43(\mathrm{C} 4 \mathrm{H})$ is based on the original $\mathrm{C} 4 \mathrm{H}$ probe and $42 \mathrm{RB} 1.8$, a probe resulting from a chromosome walk from C4H (D4S43). 42RB1.8 is adjacent to a partially cleaved $\mathrm{NruI}$ site located 150 $\mathrm{kb}$ from the $\mathrm{C} 4 \mathrm{H}$ and hybridizes to an $\mathrm{NruI}$ fragment of approximately $650 \mathrm{~kb}$. An NruI band of the same size is detected by the probe BS674. Coincidental comigration of bands could not be excluded by the use of other enzymes or by the analysis of double-digest patterns, because both probes appear to be located close to the opposite ends of the potentially shared $\mathrm{NruI}$ fragment. We therefore analyzed the hybridization patterns of BS674 and 42RB1.8 in DNA isolated from the blood of three different individuals and from nine different lymphoblastoid cell lines digested with the enzyme NruI (Fig. 3). The detection of the same partially cut $N r u I$ fragments in the same intensity ratio in DNA from different sources by these probes strongly suggests that the hybridization of the $650-\mathrm{kb}$ band is due not to random comigration of two different fragments of identical size, but to the location of both probes on the same restriction fragment.

Localization of the probes BS674 and BJ56 is based on their hybridization to identical NotI and MluI fragments. BJ56 does, however, hybridize to a 120-kb NruI fragment different from that detected by BS674. This leads to the following order of markers: BJ56-BS67442RB1.8-C4H.

The map of the distal subregion of segment II is based on the linking clones P62 (D4S113), P133 and P102 (D4S114) (Pohl et al., 1988), and P107, probes BS731 (D4S98) and BS385 (D4S99) isolated from the HHW693 lambda library (Smith et al., 1988), clone W92 (D4S114) isolated after preparative pulsed-field gel electrophoresis (Whaley et al., 1988), and clone J107 isolated by chromosome jumping from P107. All clones were localized by somatic cell hybrids to the distal region of 4p16.3 (region A) (Pohl et al., 1988; Smith et al., 1988; Whaley et al., 1988).

This region of the map of segment II is based on the closely spaced NotI linking clones P62, P133, P102, and P107 sharing a $450-\mathrm{kb} M l u I$ partial digestion product, and could be extended on one side by a cosmid isolated using P62 as probe. To extend the map on the other side, we used P107 to screen a NotI chromosome jumping library (Poustka and Lehrach, 1986, 1988; Poustka et al., 1987), containing sequences from both ends of single NotI fragments brought together by circularization and cloning of the junction fragments. The resulting jumping clone $\mathrm{J} 107$, a $50-\mathrm{kb}$ jump from $\mathrm{P} 107$, hybridized to the same $M l u I$ and $N r u I$ fragments as $\mathrm{C} 4 \mathrm{H}$. In addition, probes on the other side of the NotI 


\section{Segment I}

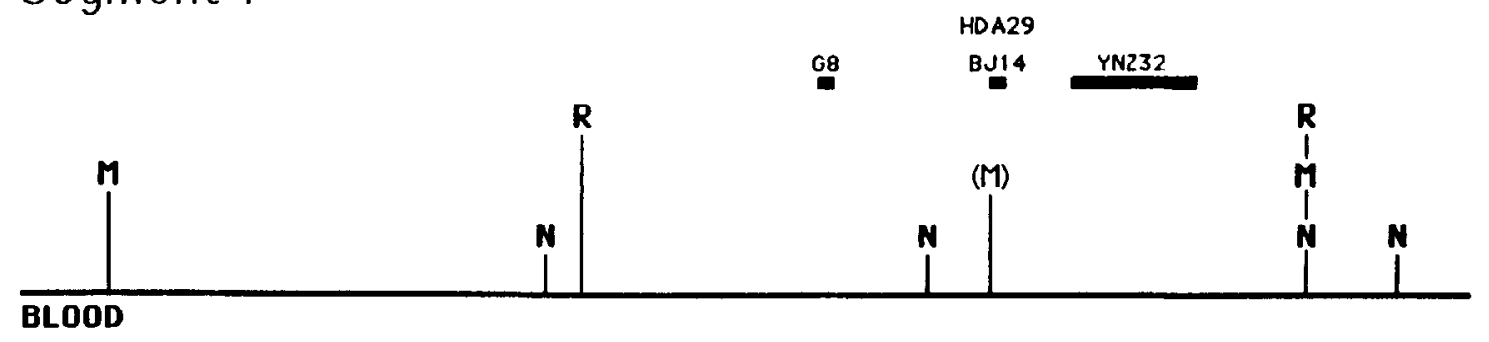

GM14168

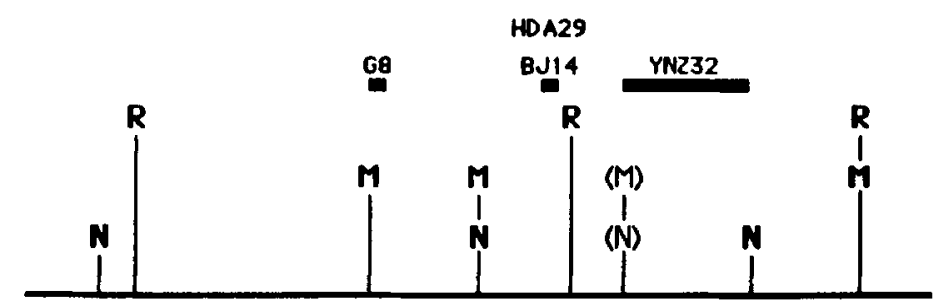

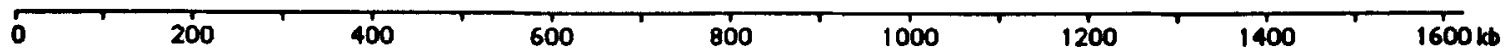

\section{Segment II}

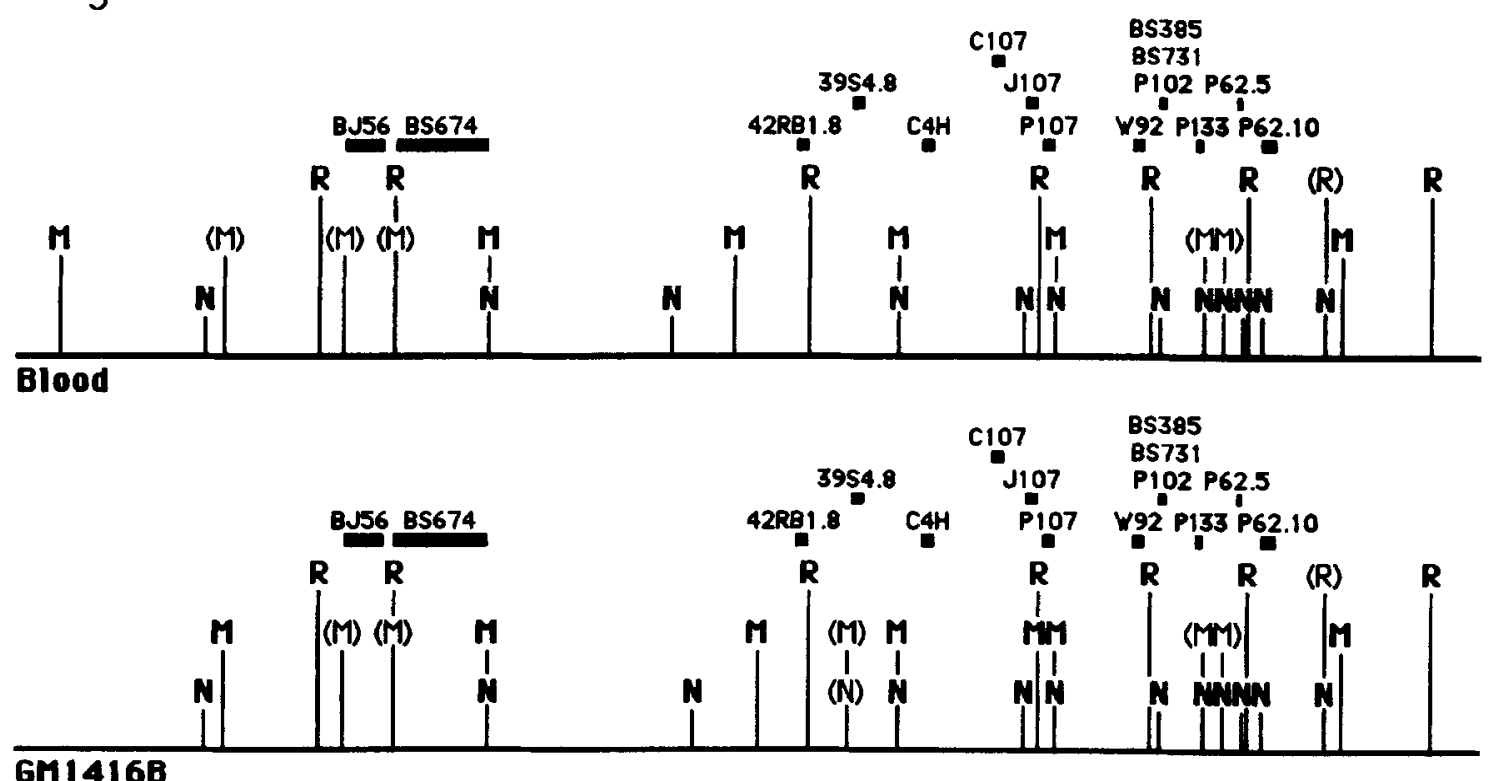

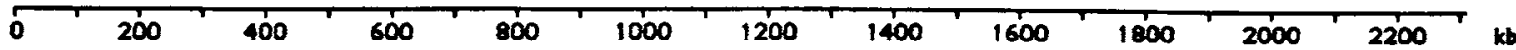

FIG. 2. Physical maps of band 4p16.3. Long-range maps of the DNA in the blood of one individual or in the cell line GM1416B were constructed by analysis of the data in Table 2. The maps indicate sites for the enzymes NotI (N), NruI (R), and MluI (M). Partially cut sites are shown in parentheses. The scale (in kb) is shown beneath the map determined with GM1416B DNA. The positions of probes are indicated by black squares above the map. Longer black boxes indicate the limits of uncertainty of probe locations.

Segment I; HDA29, pK082 (G8), BJ14, and YNZ32 all recognize two large DNA fragments in DNA isolated from peripheral blood leukocytes: an NruI fragment of approximately $800 \mathrm{~kb}$ and an MluI fragment of about $1300 \mathrm{~kb}$. All four probes detect a NotI band of $420 \mathrm{~kb}$; however, a partial NotI fragment of $520 \mathrm{~kb}$ hybridizes only to HDA29, BJ14, and YNZ32, indicating that the probe pK082 hybridizes to a different comigrating NotI fragment. In the cell line GM1416B probes pK082, BJ14, and HDA29 all detect an NruI fragment of approximately 440 kb, while YNZ32 detects an NruI fragment of about $320 \mathrm{~kb}$ in length. These results suggest that the probes BJ14 and HDA29 map between pK082 and YNZ32. Probes BJ14 and HDA29 show the same hybridization pattern using MluI, NotI, and NruI single and double digests. Hybridization 

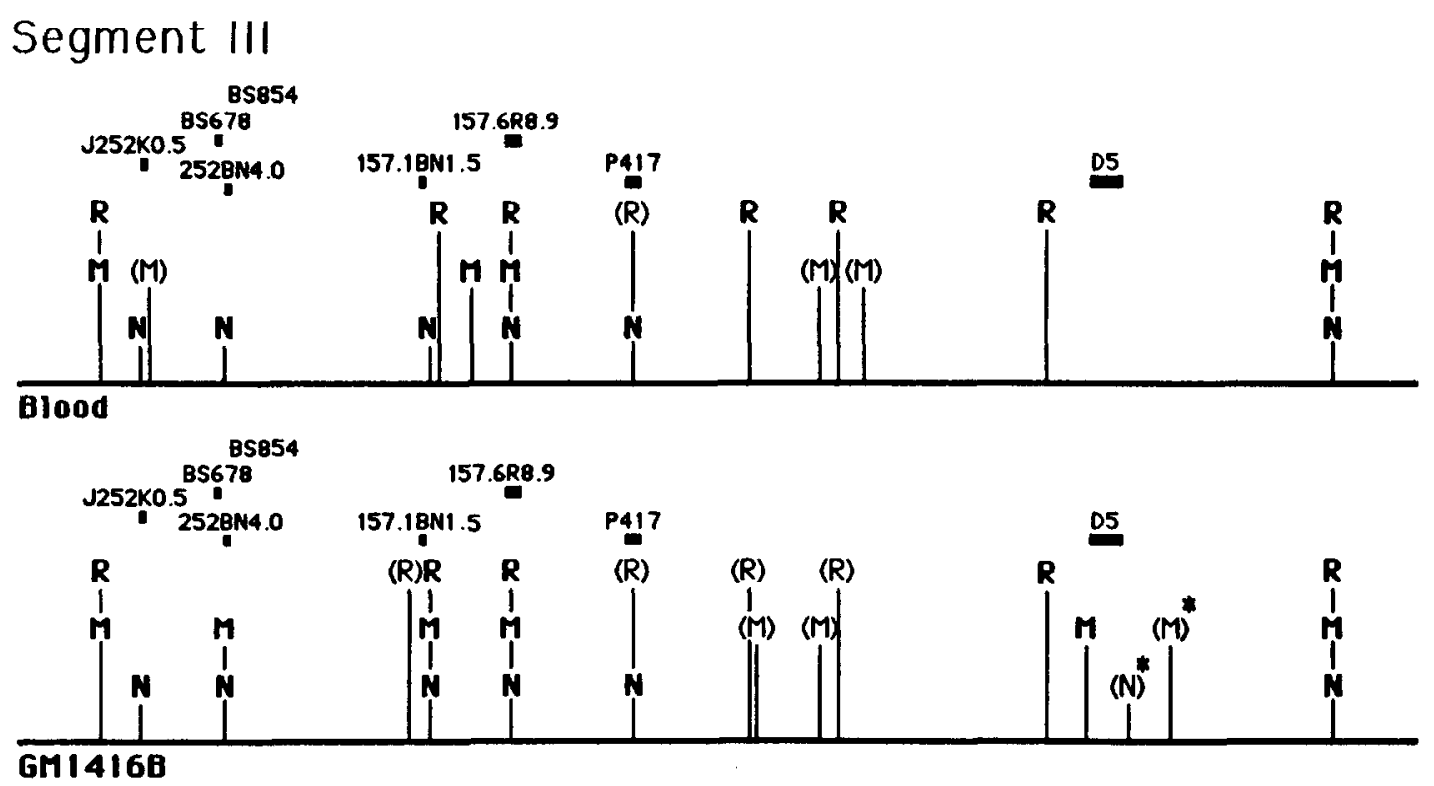

\begin{tabular}{cccccccc}
\hline 200 & 400 & 600 & 600 & 1000 & 1200 & 1400 & 1600 \\
& Fig. 2-Continued
\end{tabular}

site isolated from a cosmid clone identified by $\mathrm{J} 107$ also hybridized to the same NotI and NruI fragments as $\mathrm{C} 4 \mathrm{H}$, verifying the connection between the proximal and the distal parts of segment II.

This establishes the final order of markers as BJ56BS674-42RB1.8-C4H-J107-P107-W92-P102-P62 embedded in a map covering approximately $2.2 \mathrm{Mb}$. Using four enzyme digests (NotI, MluI, NruI, and SalI) no shared restriction fragments between YNZ32, the most distal probe of segment I, and BJ56, the most proximal probe of segment II, could be detected.

\section{Segment III}

Map segment III (Fig. 2C) was established using the linking clones $\mathrm{P} 157$ and $\mathrm{P} 417$, the jumping clones $\mathrm{J} 157$ (linking clone $\mathrm{P} 252$ ) and J252, probes from a chromosomal walk from P157, and the probe D5 (D4S90) isolated from a chromosome 4-specific library and mapped to the distal portion of 4 p16.3 (region A) (Youngman et al., 1988; Youngman et al., 1989). D4S90 (D5) was mapped by linkage analysis to a position 6 cM distal of D4S10 (Youngman et al., 1989; MacDonald et al., 1989), distal to all other described markers.

The clone P157 was isolated from a NotI linking library and mapped by somatic cell hybrids to the distal portion of 4p16.3 (Pohl et al., 1988). To expand the PFGE map and to isolate genetic and physical markers from the vicinity of $\mathrm{P} 157$ we used the fragment 157.1BN1.5, which flanks the NotI site, to screen a NotI chromosome jumping library. Two clones hybridizing to the start probe were identified. The endpoints of both jumps were mapped to the subregion $\mathrm{A}$ by so-

to the MluI + NruI and NruI + NotI fragments of $100 \mathrm{~kb}$ detected by both probes shows that the distance between them is less than $100 \mathrm{~kb}$. Since YNZ32 has been located 200-300 kb distal to BJ14/HDA29 the total distance between G8 and YNZ32 is 300-400 kb. The distance hetween pKO82 and HDA29 has been determined by Richards et al. (1988).

Segment II: Probes BS674 and BJ56 detect a NotI fragment of approximately $500 \mathrm{~kb}$ and two MluI fragments of 440 and $680 \mathrm{~kb}$ in blood, but probe BJ56 does not detect the 650-kb NruI fragment to which BS674 hybridizes. Hybridization of BJ56 to an NruI fragment of $120 \mathrm{~kb}$ suggests the following order of the four probes: $\mathrm{C} 4 \mathrm{H}, 42 \mathrm{RB} 1.8, \mathrm{BS674}$, BJ56. The map of the region around these four probes covers approximately $1.5 \mathrm{Mb}$ and permits determination of the distance between $\mathrm{C4H}$, BS674, and BJ56: BS674 is located 700-850 kb away and BJ56, 850-900 kb away (in the same direction) from $\mathrm{C} 4 \mathrm{H}$. The presence of additional MluI and NotI sites between BS674 and 42RB1.8 cannot be excluded. P107 hybridizes to NotI and NruI/MluI fragments of $50 \mathrm{~kb}$ and detects the same MluI fragment as C4H and NruI fragment as W92. The probe W92 hybridizes to a 150-kb NotI fragment and a 170-kb NruI fragment. 62.10RB3.5 detects a 100-kb NotI fragment and two NruI fragments of 120 and $290 \mathrm{~kb}$. Three linking clones (P102, P133, P62) and the probes W92 and 62.10 all hybridize to a partial MluI fragment of $450 \mathrm{~kb}$ and an MluI fragment of $225 \mathrm{~kb}$. The analysis using double digests $N r u I+M l u I$ and NotI + MluI showed that all probes from that region detect the same partial $M l u I$ fragment of $450 \mathrm{~kb}$; however, MluI fragments of $225 \mathrm{~kb}$ represent two fragments of the same size flanking a partially cut $M l u I$ site which should be located close to the linking clone P133.

Segment III: Probes 157.6R8.9 and 417BN1.8 detect a NotI fragment of $150 \mathrm{~kb}$, an NruI fragment of $150 \mathrm{~kb}$, and two MluI fragments of approximately 380 and $1000 \mathrm{~kb}$ in DNA isolated from blood. D5 detects a NotI fragment of $850 \mathrm{~kb}$, two MluI fragments of 650 and $1000 \mathrm{~kb}$, and an NruI fragment of $350 \mathrm{~kb}$. The 180-kb NruI fragment detected by D5 cannot be observed with other probes from the region, and probably represents cross-hybridization with homologous sequences. Asterisks indicate restriction sites that are cleaved only on one chromosome. The region between 157.1 and 157.6 contains additional $M l u I$ and NruI sites not shown on this map. 


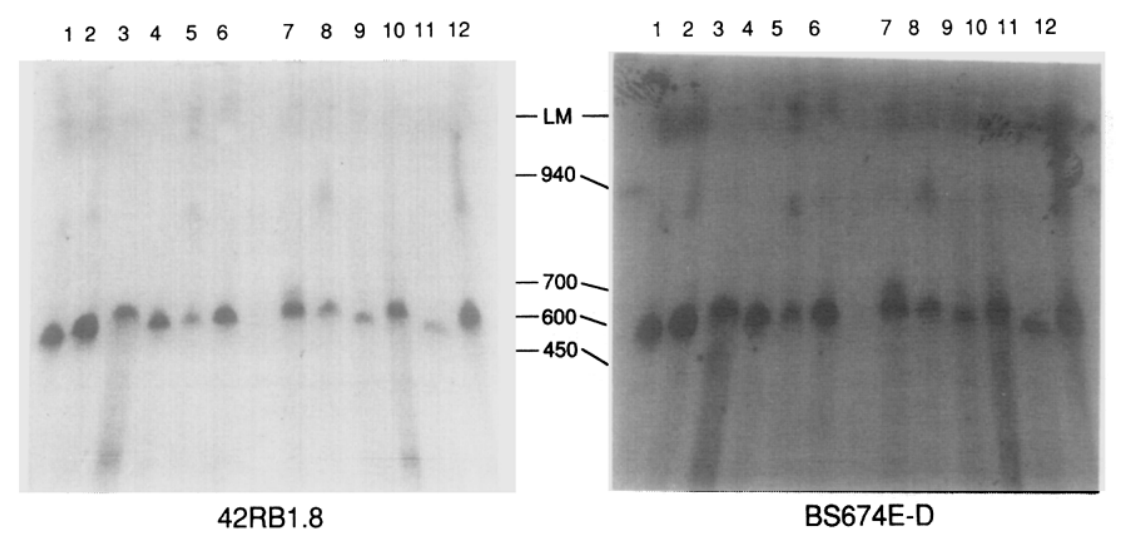

FIG. 3. Physical linkage of probes $42 \mathrm{RB} 1.8$ and BS674. High-molecular-weight DNA from the blood of three individuals $(\mathbf{1}, \mathbf{2}, \mathbf{3})$, sperm (4), and lymphoblastoid cell lines GM1416B (5), AH148 (6), GusHM1 (7), GusHM2 (8), GusHM3 (9), Gus641 (10), Gus115 (11), and EJ167T12 (12) was digested with the enzyme NruI. Electrophoresis was carried out for $40 \mathrm{~h}$ in a $0.75 \%$ agarose gel at an electric field gradient of $5 \mathrm{~V} / \mathrm{cm}$, with a pulse time of $100 \mathrm{~s}$, at $14^{\circ} \mathrm{C}$. The filter was analyzed by hybridization with the probes $42 \mathrm{RB} 1.8$ and BS674. Probes 42RB1.8 and BS674 detect only one strong fragment of $650 \mathrm{~kb}$ in DNA from 12 different sources. In addition, both probes detect the same weak partially digested fragment of $900 \mathrm{~kb}$ in DNA isolated from cell lines GM1416B and GusHM2, and a partially digested fragment of $700 \mathrm{~kb}$ in DNA from cell line GusHM1.

matic cell hybrids and localized relative to the startpoint by PFGE analysis (Fig. 4). Startpoint clone 157.1BN1.5 and endpoint 252BN4.0 are located on opposite ends of the 250 -kb NotI fragment. In contrast, a probe from the endpoint of the other jump (J252K0.5) hybridizes to a NotI fragment of $100 \mathrm{~kb}$, suggesting, that this clone represents a jump over a NotI site only partially cleaved during library construction, positioning the endpoint of this jump $350(250+100) \mathrm{kb}$ from the start. This interpretation was confirmed by isolating a linking clone (P252) which detects two adjacent NotI fragments of 100 and $250 \mathrm{~kb}$.

Two clones isolated from the HHW693 lambda library, BS854 and BS678 (Smith et al., 1988), map in the vicinity of P252. The probe BS854 shows the same hybridization pattern as 252BN4.0, localizing BS854 between 252BN4.0 and 157.1BN1.5. The probe BS678 was shown to hybridize to a cosmid isolated using $252 \mathrm{BN} 4.0$ as a probe, and is located between $252 \mathrm{BN} 4.0$ and J252.

Since fragments in the direction opposite to the jumps 252 and J252 were small, the cloned region was extended in this direction by cosmid walking through a region containing a number of well-cleaved NotI, NruI, and MluI sites (Zimmer et al., unpublished). The map was then further extended with the probe 157.6R8.9 located $100 \mathrm{~kb}$ away from the linking clone P157, flanking well-cleaved NruI, NotI, and MluI sites. $D 5$, the only remaining region A probe, could initially not be unequivocally connected to the other probes. There was, however, hybridization of both 157.6R8.9 and D5 to a 1000-kb MluI partial digestion product. Using the strategy applied before in verifying linkage between the markers BS674 and 42RB1.8, we took advantage of methylation (or sequence) polymorphism to verify the location of 157.6R8.9 and D5 on the iden- tical MluI fragment. Both probes were successively hybridized to the same filter containing 15 DNA samples isolated from the blood of different individuals and from different lymphoblastoid cell lines (Fig. 5). The same hybridization pattern and identical intensity ratios between MluI partial bands detected by D5 and 157.6R8.9 confirmed that the two probes hybridize to the same $1000-\mathrm{kb}$ partial MluI fragment. The physical linkage of 157.6R8.9 and D5 was proven by linking clone P417 that detects the same MluI partially cut band and shares one NotI fragment with 157.6R8.9 and the other with D5. The analysis of the probe D5 in DNA isolated from GM1416B allowed the construction of the map around D5, placing this probe $700-750 \mathrm{~kb}$ away from 157.6R8.9.

In constructing the map of this region in GM1416B, the observed hybridization pattern can be explained by postulating different methylation profiles on the two homologous chromosomes (Fig. 2c). In this context, it is interesting to note that imprinting by differential methylation of paternal and maternal chromosomes has been suggested as a possible source of the difference in the age of onset of paternally and maternally transmitted chromosomes in HD (Erickson, 1985; Reik, 1988).

No evidence for physical linkage between segments I and II was detected. The other end of the map is defined by a site observed with all enzymes tested (NotI, MluI, NruI, SalI, BssHII). No fragments resulting from either partial or complete restriction digest extending beyond this site were observed indicating either a cluster of very well cut rare cutter restriction sites or possibly the end of the chromosome. Since repeated attempts to reach the position next to the presumptive island by either chromosome jumping in a BssHII chromosome jumping library or by the selective cloning 


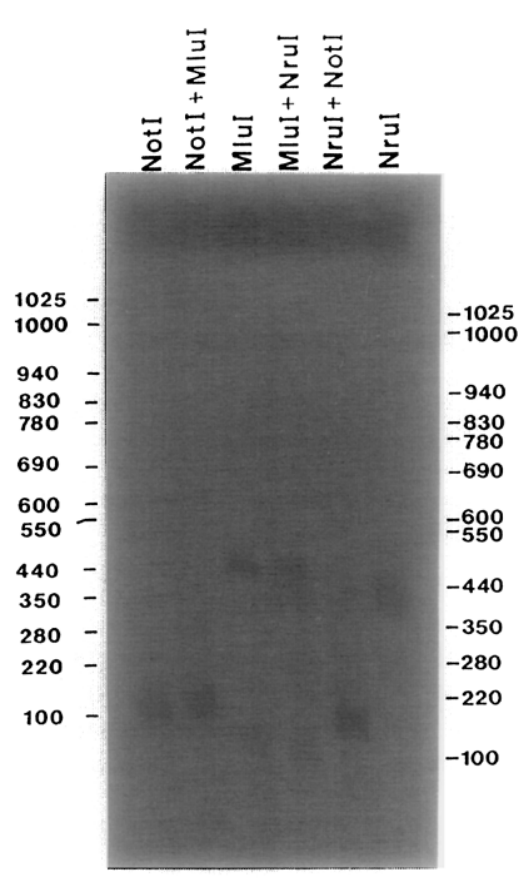

J252K0.5

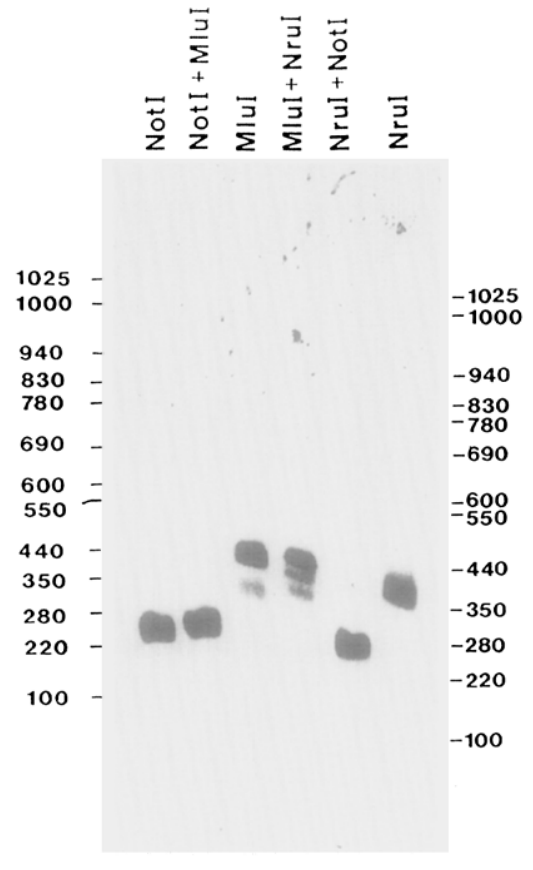

252BN4.0

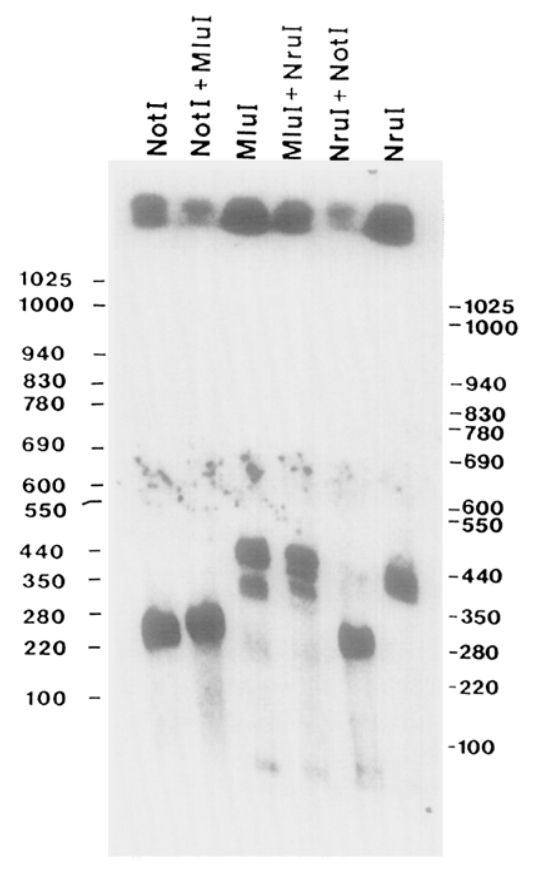

157.1BN1.5

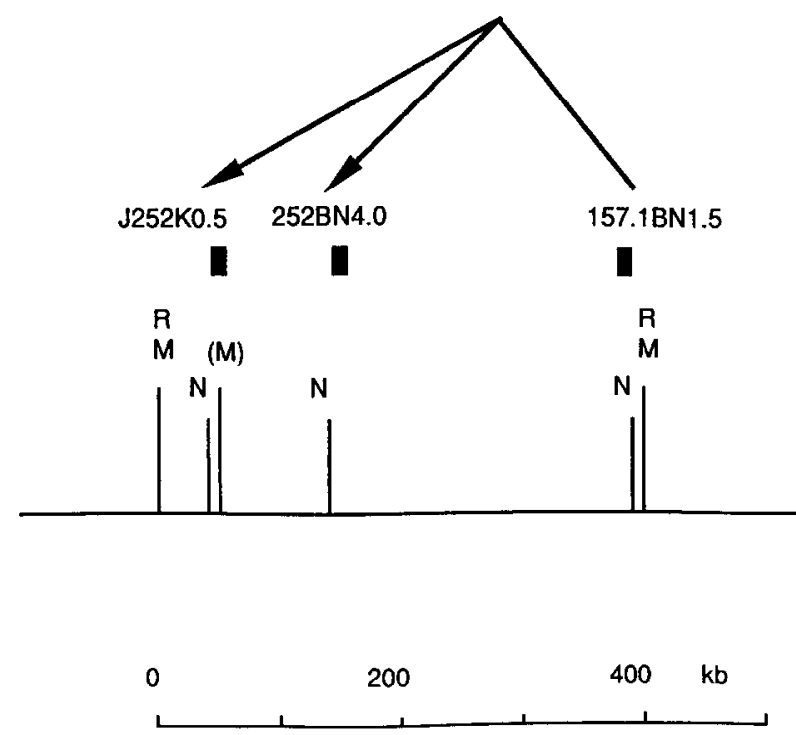

FIG. 4. Chromosome jumping from linking clone 157. (Top) PFGE analysis of the startpoint clone (157.1BN1.5) and the two endpoints (252BN4.0, J252K0.5). High-molecular-weight DNA was prepared from peripheral blood leukocytes and digested with NotI, MluI, NruI, and combinations thereof. Electrophoresis was carried out for $40 \mathrm{~h}$ in a $0.75 \%$ agarose gel at an electric field gradient of $5 \mathrm{~V} / \mathrm{cm}$, at $14^{\circ} \mathrm{C}$, with a pulse time of $100 \mathrm{~s}$. The filters were analyzed by hybridization with the probes J252K0.5, 252BN4.0, and 157.1BN1.5. (Bottom) Long-range map of the region surrounding the startpoint probe $157.1 \mathrm{BN} 1.5$ and the endpoints probes $252 \mathrm{BN} 4.0$ and J252K0.5. The map indicates sites for the enzymes NotI (N), NruI (R), and MluI (M). Partially cut sites are shown in parentheses. The scale (in kb) is shown beneath the map. The positions of probes are indicated by black squares above the map. The arrows indicate the direction of jumps relative to the startpoint. Both the startpoint probe 157.1BN1.5 and a probe from one of the endpoints (252BN4.0) hybridize to a NotI fragment of about $250 \mathrm{~kb}$, two MluI fragments of about 380 and $440 \mathrm{~kb}$, and an NruI fragment of $400 \mathrm{~kb}$ in blood DNA (top, right, and middle). Using additional enzymes which cut between these two clones (BssHII, $S f$ I, and $S a l I$ ) we were able to show that the jumping clone 252 maps, as expected, to the opposite end of the NotI fragment of $250 \mathrm{~kb}$ (data not shown). A probe from the second endpoint (J252K5.0) hybridizes to a NotI fragment of $100 \mathrm{~kg}$, two MluI fragments of 60 and $450 \mathrm{kh}$, and an NruI fragment of $400 \mathrm{~kb}$, suggesting that this clone represents a jump over an uncut NotI site (top left). Clone J252 therefore maps $350 \mathrm{~kb}(250+100)$ away from the probe $157.1 \mathrm{BN} 1.5$ used as a starting point. 


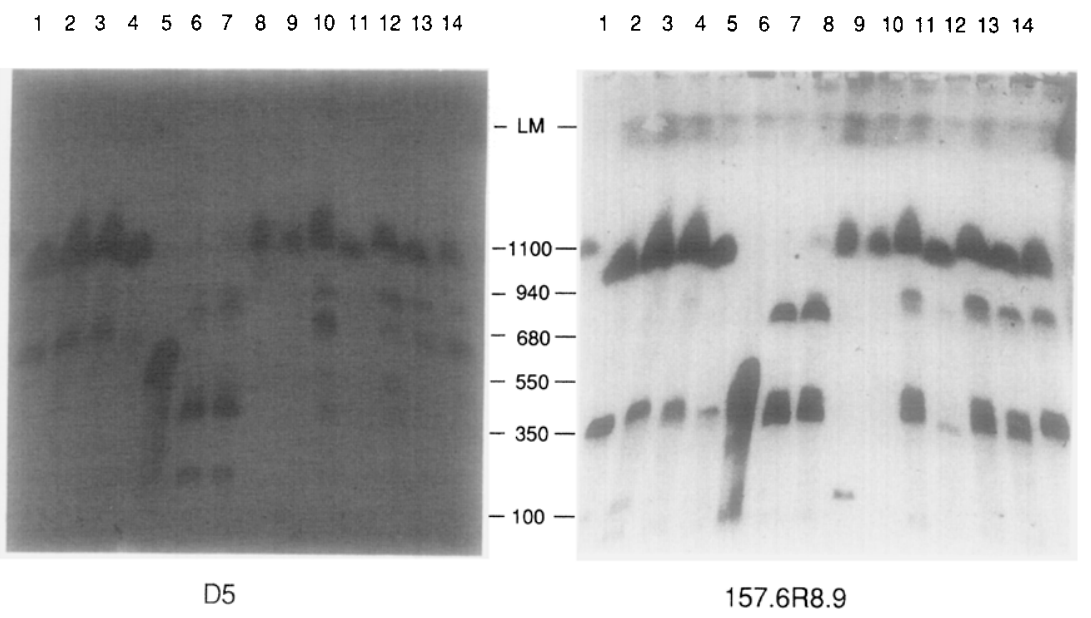

FIG. 5. Physical linkage of probes $157.6 \mathrm{R} 8.9$ and D5. High-molecular-weight DNA from the blood of four individuals (1, 2, 3, 4), sperm (5), and DNA from two different passages of the lymphoblastoid cell lines GM1416B (6, 7), HHW842 (8), HHW693 (9), Gus641 (10), Gus115 (11), two different passages of GusHM3 $(12,13)$, and GusHM1 was digested with the enzyme MluI. Electrophoresis was carried out for $40 \mathrm{~h}$ in a $0.75 \%$ agarose gel at an electric field gradient of $5 \mathrm{~V} / \mathrm{cm}$, with a pulse time of $100 \mathrm{~s}$, at $14^{\circ} \mathrm{C}$. The filter was analyzed by hybridization with the probes D5 and 157.6R8.9.

of fragments ending in NotI sites were unsuccessful, the location of an $\mathrm{CpG}$ island at this position appears unlikely, strengthening the second interpretation. This interpretation has been verified recently by the isolation of a telomere clone in a yeast artificial chromosome vector (Bates et al., submitted) covering the last 100 $\mathrm{kb}$ of the map. The endpoint of the map, drawn as a cluster of rare cutter sites, is therefore the end of the chromosome.

The map segment around D4S112 (J252), D4S115 (252), D4S97 (BS854), D4S111 (P157), D4S96 (BS678), and D4S90 (D5) covers 1.5 Mb. Genetic linkage data (Youngman et al., 1989; MacDonald et al., 1989) allowed the orientation of segment III on the chromosome, positioning $D 4 S 90$ (D5) distal to the $D 4 S 111$ (157) region, with three-point crosses showing the order cen-D4S10-D4S111-D4S90-tel.

\section{Order and Orientation of Segments along the Chromosome}

The combination of physical, genetic, and somatic cell hybrid mapping data allowed the establishment of a map of the region $4 \mathrm{p} 16.3$ covering at least $5 \mathrm{Mb}$. This map consists of three segments, which have been ordered and oriented by genetic linkage analysis and somatic cell hybrid data.

\section{Segment I G8-(BJ14-HDA29)-YNZ32 \\ Segment II BJ56-BS674-C4H-J107-P107-W92- (P102-BS731-BS385)-P133-P62 \\ Segment III J252-P252-P157-P417-D5}

The relative order of the maps along the chromosome, with segment $I$ being the most centromeric and segment
III the most telomeric (Fig. 6), was determined using somatic cell hybrids and genetic linkage analysis with polymorphic markers from each segment. The probes from the region covered by segment I and a part of segment II are located within the proximal part of $4 \mathrm{p} 16.3$, and probes from the region covered by the rest of segment II and segment III lie within the distal portion of $4 \mathrm{p} 16.3$. To further define the order of the maps, we used data from genetic linkage analysis in the CEPH and Venezuela reference family, and in HD pedigrees. Genetic linkage data using G8 and $\mathrm{C} 4 \mathrm{H}$ (Gilliam et al., 1987a; MacDonald et al., 1989) and G8 and BS674 (Wasmuth et al., 1988) placed segment I proximal to segment II. Genetic linkage data described by Youngman et al. (1989) and MacDonald et al. (1989) suggest the following order of markers: G8-(BS674-C4H)(BS731, W92, P62)-(P252, BS678, P157)-D5. This order of probes indicates that segment II maps proximal to segment III.

\section{High Density of Unmethylated CpG Sequences}

We observed a general high density of unmethylated CpG islands in $4 p 16.3$, reflected by the exceptionally small restriction fragments generated by rare cutting enzymes in many parts of the map. While the average spacing of unmethylated NotI sites in the human genome was estimated as $750 \mathrm{~kb}$ (Lindsay and Bird, 1987), the average size of fragments generated by NotI in this region is only $170 \mathrm{~kb}$. This phenomenon is especially apparent in two regions, P102-P133-P62 and 157.1-157.6, where a very high density of unmethylated $\mathrm{CpG}$ sequences in regions of $100 \mathrm{~kb}$ has been observed. The analysis of some DNA fragments flanking unmethylated $\mathrm{CpG}$ islands showed their cross-hybridization with other species (Zimmer et al., unpublished). 


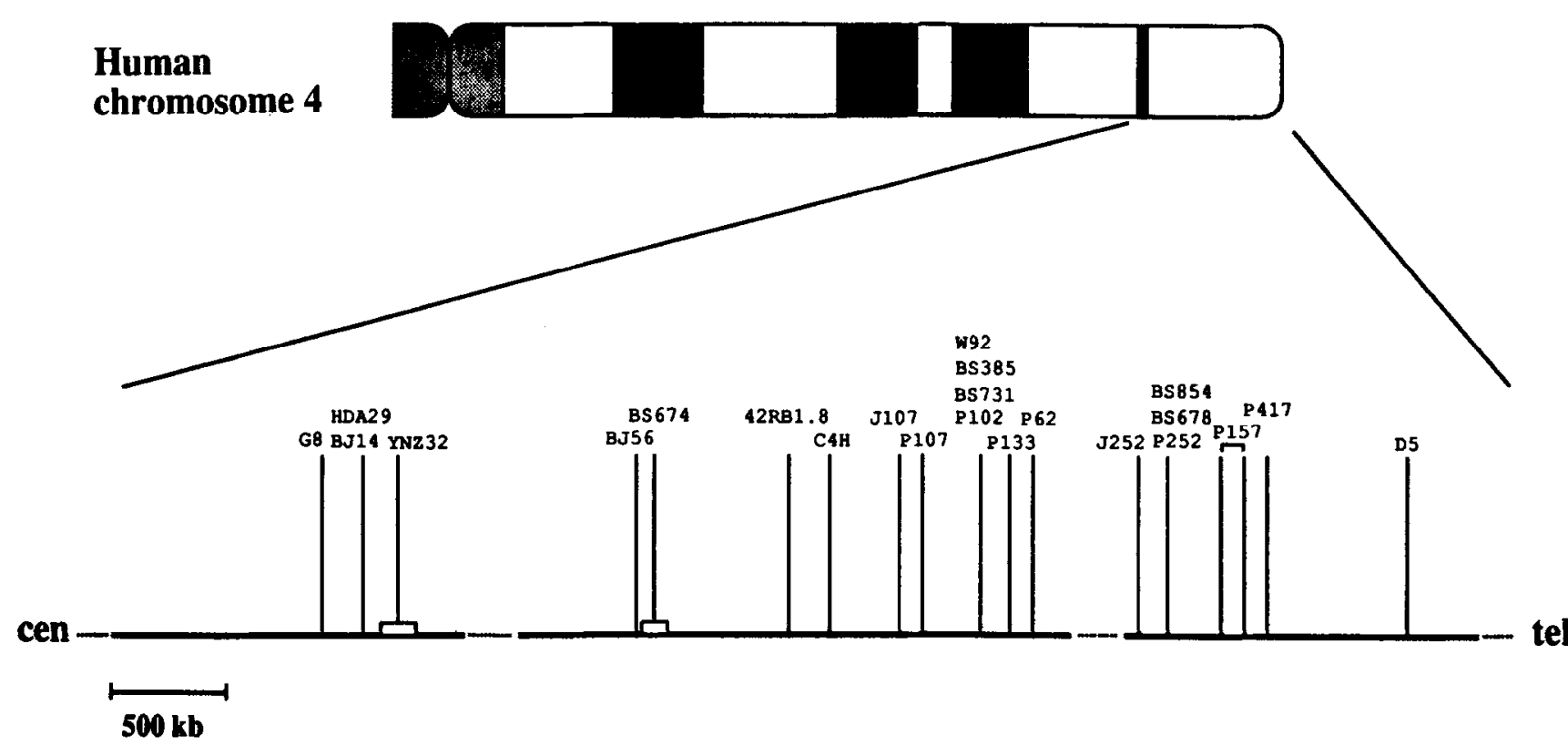

FIG. 6. Summary map of $4 \mathrm{p} 16.3$ region linking map segments I, II, and III together. The map shows the position of 23 molecular markers from the 4p16.3 region grouped into three clusters (I, II, III). The telomere-centromere orientation is shown (tel; cen). The gaps between segments are indicated by dotted lines.

These conserved sequences may represent genes often found near unmethylated $\mathrm{CpG}$ islands (Brown and Bird, 1986) or may simply reflect an unusual structural feature of regions near telomeres (Brown, 1988). Since the region 4p16.3-4pter contains G-light-staining DNA our observation of a high density of unmethylated $\mathrm{CpG}$ isands is in agreement with recent reports of CpG-rich sequences in the G-light bands, and A/T-rich sequences in G-dark bands (Bernardi et al., 1985; Holmquist, 1987; Korenberg and Rykowski, 1988; Burmeister et al., 1988).

\section{Position of the HD Gene}

The positions of the probes with respect to the $H D$ gene can be deduced from genetic linkage data obtained by linkage analysis in HD pedigrees. Two individual recombination events between $D 4 S 114 / D 4 S 113$ and $H D$ strongly suggest that the defect is located distal to segment II, placing the $H D$ gene in the region bordered by the $D 4 S 114 / D 4 S 113$ loci and the telomere (Whaley et al., 1988). However, genetic linkage analysis using polymorphic markers from segment III, located distal to $D 4 S 114$, provides equivocal information as to whether the disease gene maps between segments II and III or within the distal part of segment III (MacDonald et al., 1989).

D4S10 was mapped by somatic cell hybrids (Gusella et al., 1983) and in situ hybridization (Magenis et al., 1986; Landegent et al., 1986) to 4p16.3, the terminal subband of the short arm. If DNA were evenly distributed along the cytogenetic length of the chromosome, the upper limit for the region between $D 4 S 10$ and the telomere would correspond to approximately $6 \times 10^{6}$ bp, $0.2 \%$ of the human genome (Gilliam et al., 1987b). The physical map of $4 \mathrm{p} 16.3$ presented in this paper is distributed over at least $5 \mathrm{Mb}$, suggesting that the distance between $D 4 S 10$ and the telomere is minimally $4.3 \mathrm{Mb}$. This implies that the majority of the region $4 \mathrm{p} 16.3$ is covered by the map and that the gaps between the three segments should not be large. Since it has been shown that the $H D$ gene maps either between segments II and III or at the distal end of segment III, future effort will be devoted to bridge the gap between these segments and to obtain probes located distal to D5.

\section{ACKNOWLEDGMENTS}

We thank Peter Harper for support and discussions, Y. Nakamura and R. White for the probe YNZ32, Charles Cantor and Cassandra Smith for discussions on PFGE, Denise Barlow for help in setting up the pulsed-field gel system, Günther Zehetner for the computer program for map drawings, Lisa Stubbs, Peter Goodfellow, and Tony Monaco for critical comments on the manuscript, and Michele Price for preparing the manuscript. This work was partly supported by a grant from the Hereditary Disease Foundation.

\section{REFERENCES}

1. Barlow, D. P., AND Lehrach, H. (1987). Genetics by gel electrophoresis: The impact of pulsed field gel electrophoresis on mammalian genetics. Trends Genet. 3: 167-171.

2. Bernardi, G., Olofsson, B., Filipski, J., Zerial, M., SAlinas, J., CUNy, G., MEUNIER-Rotival, M., AND RodiER, F. (1985). The mosaic genome of warm-blooded vertebrates. Science 228: 953-958. 
3. BRown, W. R. (1988). A physical map of the human pseudoautosomal region. EMBO J. 7: 2377-2385.

4. BRown, W. R. A., AND BIRD, A. (1986). Long-range restriction site mapping of mammalian genomic DNA. Nature (London) 322: $477-481$.

5. Bucan, M., Yang-Feng, T., Colberg-Poley, A. M., WolGEMUTH, D. J., GUENET, J-L., FranCKE, U., AND LeHRACH, H. (1986). Genetic and cytogenetic localization of the homeo hox containing genes on mouse chromosome 6 and human chromosome 7. EMBO J. 5: 2899-2905.

6. Burmeister, M., Monaco, A. P., Gillard, E. F., Van OMmen, G-J. B., Affara, N. A., Ferguson-Smith, M. A., Kunkel, L. M., AND LEHRACH, H. (1988). A 10-megabase physical map of human Xp21, including the Duchenne muscular dystrophy gene. Genomics 2: 189-202.

7. Carle, G. F., Frank, M., and Olson, M., V. (1986). Electrophoretic separation of large DNA molecules by periodic inversion of the electric field. Science 232: 65-68.

8. ChU, G., Vollrath, D., AND Davis, R. W. (1986). Separation of large DNA molecules by contour-clamped homogenous electric fields. Science 234: 1582-1585.

9. ChuRCH, G. M., AND GilbERT, W. (1984). Genomic sequencing. Proc. Natl. Acad Sci. USA 81: 1991-1995.

10. ERICKSON, R. P. (1985). Chromosome imprinting and the parent transmission specific variation in expressivity of Huntington disease. Amer. J. Hum. Genet. 37: 827-829.

11. Feinberg, A. P., ANd Vogelstein, B. (1983). A technique for radiolabeling DNA restriction endonuclease fragments to high specific activity. Anal. Biochem. 132: 6-13.

12. Gilliam, T. C., BuCan, M., Macdonald, M. E., Zimmer, M., Haines, J. L., Cheng, S. V., Pohl, T. M., MeYers, R. H., Whaley, W. L., Allitto, B. A., Faryniarz, A., Wasmuth, J. J., FrischaUf, A.-M., CONNEALly, P. M., LEHRACH, H., AND GUSELLA, J. (1987a). A DNA segment encoding two genes very tightly linked to Huntington's disease. Science 238: 950-952.

13. Gilliam, T. C., Tanzi, R. E., Haines, J. L., Bonner, T. I., Faryniarz, A. G., Hobbs, W. J., Macdonald, M. E., Cheng, S. V., Folstein, S. E., Conneally, P. M., WEXler, N. S., AND GUSELLA, J. F. (1987b). Localization of the Huntington's disease gene to a small segraent of chromosome 4 flanked by D4S10 and the telomere. Cell 50: 565-571.

14. Gusella, J. F., Wexler, N. S., Conneally, P. M., Naylor, S. L., ANDERSON, M. A., TANZI, R. E., WATKINS, P. C., OTTINA, K., Wallace, M. R., SaKaguchI, A. Y., Young, A. B., SHoulSON, I., BONILLA, E., AND MARTIN, J. B. (1983). A polymorphic DNA marker genetically linked to Huntington's disease. Nature (London) 306: 234-238.

15. Gusella, J. F., Tanzi, R. E., Bader, P. I., Phelan, M. C., Stevenson, R., Hayden, M. R., Hofman, K. J., Faryniarz, A. G., AND GIBBONS, K. (1985). Deletion of Huntington's disease-linked G8 (D4S10) locus in Wolf-Hirschhorn syndrome. Nature (London) 318: 75-78.

16. HAYDEN, M. R. (1981). "Huntington's Chorea," Springer-Verlag, Berlin/Heidelberg/New York.

17. HerrmanN, B. G., Barlow, D. P., AND Lehrach, H. (1987). A large inverted duplication allows homologous recombination between chromosomes heterozygous for the proximal $t$ complex inversion. Cell 48: 813-825.

18. Herrmann, B. G., BuĆan, M., Mains, P. E., Frischauf, A.-M., SILVER, L. M., AND LEHRACH, H. (1986). Genetic analysis of the proximal portion of the mouse $t$ complex: Evidence for a second inversion within $t$ haplotypes. Cell 44: 469-476.

19. HerrmanN, B. G., AND Frischauf, A.-M. (1987). Isolation of Genomic DNA. In "Methods in Enzymology" (J. N. Abelson and M. I. Simon, Eds.), Vol. 152, pp. 180-183. Academic Press, Orlando, FL.
20. HolmQUisT, G. P. (1987). Role of replication time in the control of tissue specific gene expression. Amer. J. Hum. Genet. 40: 151-173.

21. KorenberG, J. R., AND RYKowsKi, M. C. (1988). Human genome organization: Alu, lines, and the molecular structure of metaphase chromosome bands. Cell 53: 391-400.

22. Landegent, J. E., Jansen IN DE WAL, N., Fisser-Groen, Y. M., Bakker, E., VAN der Ploeg, M., AND Pearson, P. L. (1986). Fine mapping of the Huntington disease linked D4S10 locus by non-radioactive in situ hybridization. Hum. Genet. 73: 354-357.

23. LAURIE, D. A., AND HULTEN, M. A. (1985a). Further studies on bivalent chiasma frequency in human males with normal karyotypes. Ann. Hum. Genet. 49: 189-201.

24. LaURie, D. A., AND Hulten, M. A. (1985b). Further studies on chiasma distribution and interference in the human male. Ann. Hum. Genet. 49: 203-214.

25. LINDSAY, S., AND BIRD, A. P. (1987). Use of restriction enzymes to detect potential gene sequences in mammalian DNA. Nature (London.) 327: 336-338.

26. Macdonald, M. E., Anderson, M. A., Gilliam, T. C., TraneBJAERG, L., CARPENTER, N. J., MAGENIS, E., HAYdEN, M. R., Healey, S. T., BonNer, T. I., AND GuSELla, J. F. (1987). A somatic cell hybrid panel for localizing DNA segments near the Huntington's disease gene. Genomics 1: 29 - 34.

27. Macdonald, M. E., Haines, J. L., Zimmer, M., Cheng, S. V., Youngman, S., WhaleY, W. L., WEXLER, N., BuCAN, M., ALLITTO, B. A., SMITH, B., LEAVITT, J., POUSTKA, A., HARPER, P., LEHRACH, H., WASMUTH, J. J., FrISCHAUF, A.-M., AND GUSELLA, J. F. (1989). Recombination events suggest potential sites for the Huntington's disease gene. Neuron 3: 183-190.

28. Magenis, R. E., Gusella, J., Weliky, K., Olson, S., Haight, G., TOTH-FEJEL, S., AND SHEEHY, R. (1986). Huntington disease-linked restriction fragment length polymorphism localized within band p16.1 of chromosome 4 by in situ hybridization. Amer. J. Hum. Genet. 39: 383-391.

29. Michiels, F., BuRMeister, M., AND Lehrach, H. (1987). Derivation of clones close to met by preparative field inversion gel electrophoresis. Science 236: 1305-1308.

30. Nakamura, Y., Culver, M., O'ConNell, P. O., LePPERT, M., LATHROP, G. M., LALOUEL, J.-M., AND WHITE, R. (1988). Isolation and mapping of a polymorphic DNA sequence (pYNZ32) on chromosome 4p (D4S125). Nucl. Acids Res. 16: 4186.

31. Pohl, T. M., Zimmer, M., MaCDONALD, M. E., SMiTH, B., BUCan, M., PoustKa, A., Volinia, S., Searle, S., ZeheTNer, G., WASMUTH, J. J., GUSELLA, J., LEHRACH, H., AND FRISCHAUF, A.-M. (1988). Construction of a NotI linking library and isolation of new markers close to the Huntington's disease gene. Nucl. Acids Res. 16: $9185-9198$.

32. POUSTKA, A., AND LeHRACH, H. (1986). Jumping libraries and linking libraries: The next generation of molecular tools in mammalian genetics. Trends Genet. 2: 174-179.

33. PoustKa, A., AND LeHRaCh, H. (1988). Chromosome jumping: A long range cloning technique. In "Genetic EngineeringPrinciples and Methods" (J. K. Setlow, Ed.), Vol. 10, pp. 169195, Plenum, New York.

34. Poustka, A., Pohl, T. M., Barlow, D. P., Frischauf, A.-M., AND LEHRACH, H. (1987). Construction and use of human chromosome jumping libraries from NotI-digested DNA. Nature (London) 325: 353-355.

35. REIK, W. (1988). Genomic imprinting: A possible mechanism for the parental origin effect in Huntington's chorea. J. Med. Genet. 25: 805-808.

36. Richards, J. E., Gilliam, C. T., Cole, J. L., DRUMM, M. L., WAsmuth, J. J., GuSella, J. F., AND Collins, F. S. (1988). 
Chromosome jumping from D4S10 (G8) towards the Huntington disease gene. Proc. Natl. Acad. Sci. USA 85: 6437-6441.

37. SCHWARTZ, D. C., AND CANTOR, C. R. (1984). Separation of yeast chromosome-sized DNAs by pulsed field gradient gel electrophoresis. Cell 37: 67-75.

38. Smith, B., Skarecky, D., Bengtsson, U., Magenis, R. E., CARPENTER, N., AND WASMUTH, J. J. (1988). Isolation of DNA markers in the direction of the Huntington disease gene from the G8 locus. Amer. J. Hum. Genet. 42: 335-344.

39. Wasmuth, J. J., Carlock, L. R., SMITH, B., AND IMmken, L. L. (1986). A cell hybrid and recombinant DNA library that facilitate identification of polymorphic loci in the vicinity of the Huntington's disease gene. Amer. J. Hum. Genet. 39: 397403.

40. Wasmuth, J. J., HewitT, J., Smith, B., Allard, D., Haines, J. L., Skarecky, D., Partlow, E., AND Hayden, M. R. (1988). A highly polymorphic locus very tightly linked to the Huntington's disease. Nature (London) 332: 734-736.

41. Wexler, N. S., Young, A. B., Tanzi, R. E., Travers, H., Starosta-Rubinstein, S., Penney, J. B., SnOdgrass, S. R., Shoulson, I., Gomez, F., Ramos-Arroyo, M. A., Penchas-
Zadeh, G. K., Moreno, H., Gibbons, K., Faryniarz, A., HobBs, W., ANderson, M. A., Bonilla, E., Conneally, P. M., AND GUSELLA, J. F. (1987). Homozygotes for Huntington's disease. Nature (London) 326: 194-197.

42. Whaley, W. L., Michiels, F., Macdonald, M. E., Romano, D., ZIMMER, M., SMITH, B., LEAVITT, J., BUCAN, M., HAINES, J., Gilliam, T. C., ZeheTner, G., Frischauf, A.-M., WasMUTH, J. J., LEHRACH, H., AND GUSELLA, J. F. (1988). Mapping of D4S98/S114/S113 confines the Huntington's defect to a reduced physical region at the telomere of chromosome 4 . Nucl. Acids Res. 16: 11769-11780.

43. Youngman, S., Shaw, D. J., Gusella, J. F., Macdonald, M. E., STANBRIDGE, E. J., WASMUTH, J. J., AND HARPER, P. S. (1988). A DNA probe, D5 (D4S90), mapping to human chromosome 4p16.3. Nucl. Acids Res. 16: 1648.

44. Youngman, S., Sarfarazi, M., BuCan, M., Macdonald, M., SMITH, B., ZimMER, M., GilliaM, C., Frischauf, A-M., WASMUTH, J. J., GuSElla, J. F., Lehrach, H., HaRPER, P., AND SHAW, D. (1989). A new DNA marker [D4S90] is located terminally on the short arm of chromosome 4, close to the Huntington's Disease Gene. Genomics, in press. 